GOD'S PLANET 



\section{GOD'S PLANET}

Owen Gingerich

\section{III}

III

Harvard University Press

Cambridge, Massacbusetts

London, England

2014 
Copyright (C) 2014 by the President and Fellows of Harvard College All rights reserved

Printed in the United States of America

First printing

Library of Congress Cataloging-in-Publication Data

Gingerich, Owen.

God's planet / Owen Gingerich.

pages $\mathrm{cm}$

Includes bibliographical references and index.

ISBN 978-o-674-41710-6 (alk. paper)

I. Religion and science. 2. Copernicus, Nicolaus,

1473-1543. 3. Darwin, Charles, I8o9-I882. 4. Hoyle,

Fred, 1915-20or. I. Title.

BL240.3.G558 2014

$215-\mathrm{dc} 23 \quad 2014012008$ 
To Miriam 
